\title{
Komunikasi dan Disiplin Kerja dalam Mempengaruhi Kinerja Karyawan
}

\author{
Communication and Work Discipline in Influencing Employee \\ Performance
}

Oleh :

\author{
Muh. Ali Maskuri; Rara Arafiah; Mursida Kusuma Wardani; Hery Margono \\ Sekolah Tinggi Ilmu Ekonomi IPWI Jakarta \\ rmaskuriali@yahoo.co.id; rara.arafiah@gmail.com; idha_mkw@yahoo.com; \\ herymargono88@gmail.com
}

\begin{abstract}
ABSTRAK
Penelitian bertujuan mengetahui pengaruh Komunikasi dan Disiplin Kerja terhadap Kinerja Karyawan. Penelitian dilakukan di PT Astra Visteon Indonesia dengan mengambil 55 karyawan sebagai sampel penelitian yang dihitung menggunakan rumus Slovin dari total populasi 118 karyawan. Pengambilan data dilakukan dengan instrumen kuesioner tertutup lima skala dari sangat tidak setuju sampai dengan sangat setuju yang dianalisis secara statistik (SPSS versi 22). Analisis regresi linier ganda digunakan sebagai alat analisis sedangkan pengujian hipotesis dilakukan dengan uji-t dan uji-F. Hasil penelitian menunjukkan bahwa Komunikasi memiliki pengaruh positif dan signifikan terhadap Kinerja Karyawan dan Disiplin Kerja memiliki pengaruh positif dan signifikan terhadap Kinerja Karyawan.
\end{abstract}

Kata Kunci: Komunikasi, Disiplin Kerja, Kinerja Karyawan

\begin{abstract}
Research aims to find out the influence of Communication and Work Discipline on Employee Performance. The study was conducted at PT Astra Visteon Indonesia by taking 55 employees as a sample of research calculated using the Slovin formula from a total population of 118 employees. The data retrieval was conducted with a five-scale closed questionnaire instrument from strongly disagreeing to strongly agreeing that it was analyzed statistically (SPSS version 22). Multiple linear regression analysis is used as an analysis tool whereas hypothesis testing is done with the t-test and the F-test. The results showed that communication has a positive and significant influence on Employee Performance and Work Discipline has a positive and significant influence on Employee Performance.
\end{abstract}

Kata Kunci: Communication; Work Discipline; Performance 


\section{PENDAHULUAN}

Dalam menciptakan kualitas dan kuantitas produk serta pelayanan konsumen yang lebih baik, tentunya tidak dapat terlepas dari peran Sumber Daya Manusia (SDM) di dalam organisasi tersebut. Untuk itu SDM harus memiliki kinerja yang baik agar tujuan organisasi dapat tercapai. Setiap organisasi selalu berusaha agar kinerja karyawan dapat ditingkatkan.

PT Astra Visteon Indonesia (PT. AVI) adalah sebuah perusahaan yang bergerak dibidang manufaktur komponen otomotif elektronik. Karena bergerak dibidang manufaktur, tidak heran jika PT. AVI menjadi salah satu produsen otomotif ternama, menyediakan inovatif kelas dunia, dan produk berkualitas tinggi dimana produk utamanya adalah speedometer dan audio mobil.

Namun yang terjadi saat ini di PT Astra Visteon Indonesia, kinerja karyawannya semakin menurun menyebabkan target produksi selalu tidak tercapai. Jika dilihat dari kondisi yang ada, kinerja karyawan yang kurang tersebut diduga terjadi karena kurangnya komunikasi yang baik antar departemen.

Tidak tercapainya target produksi tersebut tentu saja membuat tim PPIC harus mengatur ulang jumlah target di hari/bulan berikutnya agar target produksi dapat tercapai. Namun, jika terus menerus tidak mencapai target tentu saja bukan hal yang tidak mungkin jika PT. AVI akan terlambat mengirimkan barang ke customer. Jika hal tersebut terjadi, maka PT. AVI akan mendapatkan complain dari customer dan jika terus menerus terjadi, customer bisa saja melepas kerja samanya dengan PT. AVI. Kehilangan customer artinya kehilangan pendapatan. Karena, pendapatan perusahaan yang utama pastinya adalah pembelian barang oleh customer. Dan bukan hal mudah untuk mendapatkan customer baru. Oleh karena itu, PT. AVI harus mampu mempertahankan customer yang sudah ada. Terlebih lagi, sebagian besar penjualan
PT. AVI adalah ke Astra Honda Motor (AHM). Jika AHM melepas kerjasamanya dengan PT. AVI, maka PT. AVI akan terancam keberadaannya.

Menurut Wandi, dkk (2019), Ardiansyah (2016) dan Ardianto (2016) menyatakan dimana komunikasi berpengaruh positif dan signifikan terhadap kinerja pegawai.

Selain komunikasi, diduga disiplin kerja pun menjadi faktor kurangnya kinerja karyawan. Dimana kondisi yang ada yaitu, adanya ketidakmampuan karyawan PPIC dalam membuat rencana produksi, menghitung stok barang sampai memprediksikan kedatangan barang.

Pangarso dan Susanti (2016), Liyas dan Primadi (2017), Yulius (2019), menyatakan disiplin kerja berpengaruh positif dan signifikan terhadap kinerja karyawan. Komunikasi yang baik antar departemen dan disiplin kerja dianggap merupakan pendorong untuk meningkatkan kinerja karyawan. Jika komunikasi terjalin dengan baik dan setiap karyawan dapat dengan disiplin melaksanakan tugas yang menjadi tanggung jawabnya, maka diharapkan tentunya kinerja karyawan pun akan baik dan hasil produksi pun akan tercapai.

Tujuan dalam penelitian ini untuk mengetahui pengaruh Komunikasi dan disiplin kerja terhadap Kinerja Karyawan pada PT Astra Visteon Indonesia.

\section{METODOLOGI PENELITIAN}

\section{Pengembangan Hipotesis}

\section{Manajemen Sumber Daya Manusia}

Menurut Panggabean (2007:15), Manajemen Sumber Daya Manusia adalah suatu proses yang terdiri atas perencanaan, pengorganisasian, kepemimpinan dan pengendalian kegiatan-kegiatan yang berkaitan dengan analisis pekerjaan, evaluasi pekerjaan, pengadaan, pengembangan, kompensasi, promosi dan pemutusan hubungan kerja guna mencapai tujuan yang ditetapkan. 
Menurut Mangkunegara (2001:2), Manajemen Sumber Daya Manusia adalah suatu perencanaan, pengorganisasian, pelaksanaan, dan pengawasan terhadap pengadaan, pengembangan, pemberian balas jasa, pengintegrasian, pemeliharaan, dan pemisahan tenaga kerja dalam rangka mencapai tujuan organisasi.

Sedangkan menurut Hasibuan (2009:10), Manajemen Sumber Daya Manusia adalah ilmu dan seni mengatur hubungan dan peranan tenaga kerja agar efektif dan efisien membantu terwujudnya tujuan perusahaan, karyawan dan masyarakat.

\section{Komunikasi}

Menurut Mangkunegara (2001:145), komunikasi dapat diartikan sebagai proses pemindahan suatu informasi, ide, pengertian dari seseorang kepada orang lain dengan harapan orang lain tersebut dapat menginterpretasikannya sesuai dengan tujuan yang dimaksud.

DeVito (2011:24) menyatakan bahwa "Komunikasi mengacu pada tindakan, oleh satu orang atau lebih, yang mengirim dan menerima pesan yang terdistorsi oleh gangguan (noise), terjadi dalam suatu konteks tertentu, mempunyai pengaruh tertentu, dan ada kesempatan untuk melakukan umpan balik"

Sedangkan menurut Sutrisno (2010:105), Komunikasi yaitu suatu proses pengiriman pesan atau simbol yang mengandung arti dari seseorang komunikator kepada komunikan dengan tujuan tertentu.

\section{Disiplin Kerja}

Menurut Sutrisno (2016:89), disiplin pegawai adalah perilaku seseorang yang sesuai dengan peraturan, prosedur kerja yang ada atau disiplin adalah sikap, tingkah laku dan perbuatan yang sesuai dengan peraturan dari organisasi baik tertulis maupun yang tidak tertulis.
Menurut Siagian (2003:305) Disiplin Kerja adalah tindakan manajemen untuk mendorong para anggota organisasi memenuhi tuntutan berbagai ketentuan tersebut. Dengan kata lain, pendisiplinan karyawan adalah suatu bentuk pelatihan yang berusaha memperbaiki dan membentuk pengetahuan, sikap dan perilaku karyawan sehingga para karyawan tersebut secara sukarela berusaha bekerja secara kooperatif dengan para karyawan lain serta meningkatkan prestasi kerjanya.

Sedangkan menurut Sastrohadiwiryo (2005:291) Disiplin Kerja adalah suatu sikap menghormati, menghargai, patuh dan taat terhadap peraturan-peraturan yang berlaku, baik yang tertulis maupun tidak tertulis serta sanggup menjalankannya dan tidak mengelak untuk menerima sanksi-sanksi apabila ia melanggar tugas atau wewenang yang diberikan kepadanya.

\section{Kinerja Karyawan}

Menurut Mangkunegara (2006:67), Kinerja merupakan hasil kerja secara kuantitas dan kualitas yang dicapai seorang pegawai dalam melaksanakan tugas dan sesuai dengan tanggung jawab yang diberikan.

Prawirosentono mendefinisikan kinerja yaitu "Performance" adalah hasil kerja yang dapat dicapai oleh seseorang atau sekelompok orang dalam organisasi sesuai dengan wewenang dan tanggungjawab masing-masing, dalam rangka upaya pencapaian tujuan organisasi bersangkutan secara legal, tidak

Sedangkan Armstrong dan Baron (dalam Wibowo 2007:2) menjelaskan bahwa kinerja (performance) adalah tentang melakukan pekerjaan dan hasil yang dicapai dari pekerjaan tersebut. Kinerja merupakan hasil pekerjaan yang mempunyai hubungan kuat dengan tujuan strategis organisasi, kepuasan konsumen dan memberikan kontribusi ekonomi". 


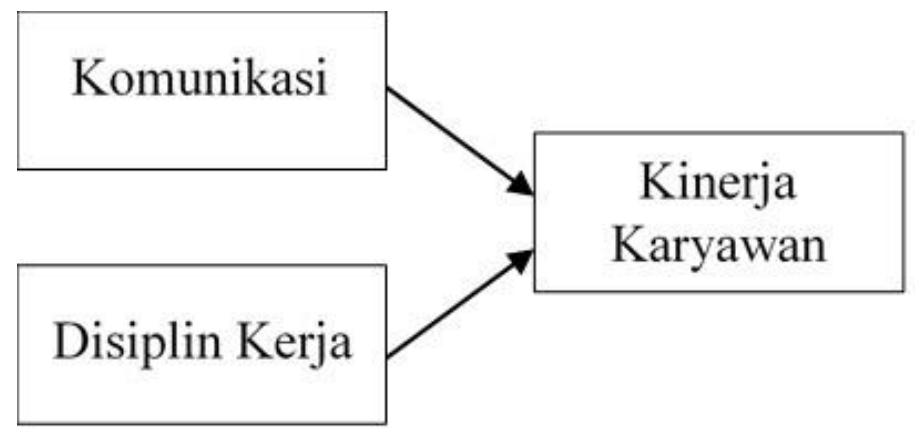

Gambar 1. Kerangka Penelitian

\section{Pengumpulan Data}

Penelitian ini dilakukan di PT Astra Visteon Indonesia Cfteureup Kab. Bogor. Populasi pada penelitian ini adalah pegawai PT Astra Visteon Indonesia yang berjumlah 118 orang (Usman, 2006: 181). Sampel pada penelitian ini adalah sebagian dari 118 pegawai PT Astra Visteon Indonesia. Agar memenuhi persyaratan minimal jumlah sampel dan memudahkan peneliti maka jumlah sampel penelitian ditetapkan sebanyak 55 pegawai. Pengambilan sampel dilakukan dengan metode Cluster Sampling berdasarkan departemen kerja. Pengumpulan data dilakukan melalui observasi dan penyebaran kuesioner.

\section{Operasionalisasi Variabel}

Guna mempermudah pemberian penjelasan dan arah penelitian tentang variabel penelitian ini maka penting untuk mendefinisikan terlebih dahulu konsep dan operasional dari masing-masing variabel yaitu variabel komunikasi, variabel disiplin kerja, dan variabel kinerja karyawan.

Tabel 1. Operasionalisasi Variabel

\begin{tabular}{|c|c|}
\hline Variabel & Indikator \\
\hline $\begin{array}{l}\text { Komunikasi }\left(\mathrm{X}_{1}\right) \text { yaitu suatu proses pengiriman pesan } \\
\text { atau simbol yang mengandung arti dari seseorang } \\
\text { komunikator kepada komunikan dengan tujuan } \\
\text { tertentu (Suranto, 2010) }\end{array}$ & $\begin{array}{l}\text { a. Pemahaman } \\
\text { b. Kesenangan } \\
\text { c. Sikap } \\
\text { d. Hubungan Tindakan }\end{array}$ \\
\hline $\begin{array}{l}\text { Disiplin Kerja }\left(\mathrm{X}_{2}\right) \text { adalah perilaku seseorang yang } \\
\text { sesuai dengan peraturan, prosedur kerja yang ada atau } \\
\text { disiplin adalah sikap, tingkah laku dan perbuatan yang } \\
\text { sesuai dengan peraturan dari organisasi baik tertulis } \\
\text { maupun yang tidak tertulis (Sutrisno, 2016) }\end{array}$ & $\begin{array}{l}\text { a. Taat aturan waktu } \\
\text { b. Taat peraturan } \\
\text { c. Taat aturan perilaku } \\
\text { pekerjaan } \\
\text { d. Taat peraturan lainnya }\end{array}$ \\
\hline $\begin{array}{l}\text { Kinerja Karyawan }(Y) \text { adalah hasil kerja yang dapat } \\
\text { dicapai oleh seseorang atau sekelompok orang dalam } \\
\text { organisasi sesuai dengan wewenang dan } \\
\text { tanggungjawab masing-masing, dalam rangka upaya } \\
\text { pencapaian tujuan organisasi bersangkutan secara } \\
\text { legal, tidak melanggar hukum dan sesuai dengan moral } \\
\text { maupun etika (Prawirosentono, 2008) }\end{array}$ & $\begin{array}{ll}\text { a. } & \text { Kualitas } \\
\text { b. } & \text { Kuantitas } \\
\text { c. } & \text { Ketepatan Waktu } \\
\text { d. } & \text { Efektivitas } \\
\text { e. } & \text { Kemandirian }\end{array}$ \\
\hline
\end{tabular}

Sumber: Rangkuman teori, 2021 


\section{Metode Analisis}

Instrumentasi variabel merupakan pengujian terhadap data hasil kuesioner. Uji instrumen penelitian dilakukan melalui uji validitas-reliabilitas untuk memastikan bahwa kuesioner yang disusun dapat dimengerti oleh responden dan memiliki konsistensi pengukuran (Ghozali, 2005:41). Analisis selanjutnya dilakukan dengan Reliability Analysis menggunakan software SPSS versi 22.

Dalam penelitian ini metode analisis yang digunakan adalah analisis regresi linier berganda. Analisis regresi linier berganda digunakan untuk mengukur pengaruh variabel independen terhadap variabel dependen. Analisis regresi linier berganda didahului uji persyaratan analisis yaitu uji asumsi klasik. Uji asumsi klasik digunakan untuk membuktikan bahwa model persaman regresi linier berganda dapat diterima secara ekonometrika karena memenuhi penaksiran BLUE (Best Linier Unbiased Estimator) artinya penaksiran tidak bias, linier dan konsisten. Uji asumsi terdiri dari uji normalitas, multikolinieritas, autokorelasi, dan heteroskedastisitas, yang dapat dijelaskan sebagai berikut (Mulyanto dan Wulandari, 2010:181):

Analisis koefisien determinasi digunakan untuk menganalisis kemampuan variabel independen Komunikasi dan Disiplin kerja dalam menjelaskan variabilitas variabel Kinerja Karyawan dalam model persamaan regresi yang dihasilkan dalam analisis. Hasil analisis berupa nilai koefisien determinasi $R$ Square (R2) yang menunjukkan berapa persentase kontribusi dari variabel Komunikasi dan Disiplin Kerja pada model dalam menjelaskan variabilitas nilai dari variabel Kinerja Karyawan. Metode analisisnya Model persamaan regresi linier ganda dengan dua variabel independen dan satu variabel dependen adalah sebagai berikut: $\mathrm{Y}=\mathrm{a}+\mathrm{b} 1 \mathrm{X} 1+\mathrm{b} 2 \mathrm{X} 2 \ldots \ldots \ldots \ldots \ldots \ldots 1)$

Sebelum dilakukan pengujian hipotesis, terlebih dahulu dilakukan uji kelayakan model. Pengujian model dilakukan dengan uji-F yaitu membandingkan nilai probabilitas (sig F) terhadap taraf uji penelitian $(\alpha=0.05)$. Pengujian hipotesis penelitian dilakukan dengan uji-t yaitu membandingkan nilai probabilitas (sig $t$ ) terhadap taraf uji penelitian $(\alpha=0.05)$.

\section{HASIL DAN PEMBAHASAN}

\section{Karakteristik Responden}

Karakteristik responden penelitian berdasarkan jenis kelamin, rentang usia, pendidikan terakhir dan masa kerja. Berikut dipaparkan hasil dari masingmasing karakteristik responden. Sebagian besar responden berjenis kelamin laki-laki yaitu sebesar 55\%, sedangkan responden berjenis kelamin perempuan yaitu $45 \%$.

Responden dengan rentang usia 21 25 tahun yaitu sebesar $49 \%$, sedangkan responden dengan rentang usia 26 - 30 tahun sebesar $24 \%$, responden dengan rentang usia 31 - 35 tahun sebesar 16\%, responden dengan rentang usia 36 - 40 tahun sebesar $7 \%$ dan responden dengan rentang usia 41 - 45 tahun sebesar $4 \%$.

Sebagian besar responden memiliki pendidikan terakhir SLTA/Sederajat sebesar 75\%, responden dengan pendidikan terakhir Diploma sebesar 13\%, responden dengan pendidikan terakhir S1 sebesar 7\%, dan responden dengan pendidikan terakhir S2 sebesar 5\%.

Sebagian besar responden dengan masa kerja 0 - 2 tahun yaitu sebesar $44 \%$, responden dengan masa kerja 3 - 4 tahun sebesar $13 \%$, responden dengan masa kerja 5 - 6 tahun sebesar $9 \%$, responden dengan masa kerja 7 - 8 tahun sebesar $11 \%$ dan responden dengan masa kerja 9 - 10 tahun sebesar $21 \%$.

\section{Hasil Uji Validitas dan Reliabilitas}

Uji validitas variabel komunikasi dilakukan terhadap 10 item pernyataan, karena hasil uji mendapatkan nilai $r$ hitung $>\mathrm{r}$ tabel (Corrected Item-Total Correlation $>0.266$ ) untuk seluruh item, maka 10 item 
indikator pengukur variabel komunikasi seluruhnya valid. Hasil uji reliabilitas terhadap variabel komunikasi yang terdiri dari 10 item pernyataan yang valid diperoleh nilai (Cronbach's Alpha) 0,855. Karena nilai Cronbach's Alpha lebih besar dari pembanding $(0,855>0,6)$ maka sebagai dasar pengambilan keputusan dalam uji reliabilitas diatas, dapat disimpulkan bahwa variabel komunikasi yang diukur menggunakan 10 item pernyataan telah reliabel.

Uji validitas variabel disiplin kerja dilakukan terhadap 10 item pernyataan. Karena hasil uji mendapatkan nilai $r$ hitung $>\mathrm{r}$ tabel (Corrected Item-Total Correlation $>0,266$ ) untuk seluruh item, maka 10 item indicator pengukur variabel disiplin kerja seluruhnya valid. Hasil uji reliabilitas terhadap variabel disiplin kerja yang terdiri dari 10 item pernyataan yang telah valid diperoleh nilai (Cronbach's Alpha) 0,850. Karena nilai Cronbach's Alpha lebih besar dari pembanding $(0,850>0,6)$ maka sebagai dasar pengambilan keputusan dalam uji reliabilitas diatas, dapat disimpulkan bahwa variabel disiplin kerja yang diukur menggunakan 10 item pernyataan telah reliabel.

Uji validitas variabel Kinerja Karyawan dilakukan terhadap 10 item pernyataan. Karena hasil uji mendapatkan nilai $\mathrm{r}$ hitung $>\mathrm{r}$ tabel (Corrected ItemTotal Correlation $>0,266$ ) untuk seluruh item, maka 10 item indikator pengukur variabel Kinerja Karyawan seluruhnya valid. Hasil uji reliabilitas terhadap variabel kinerja karyawan yang terdiri dari 10 item pernyataan yang telah valid diperoleh nilai (Cronbach's Alpha) 0,873. Karena nilai Cronbach's Alpha lebih besar dari pembanding $(0,873>0,6)$ maka sebagai dasar pengambilan keputusan dalam uji reliabilitas diatas, dapat disimpulkan bahwa variabel kinerja karaywan yang diukur menggunakan 10 item pernyataan telah reliabel.

\section{Uji Persyaratan Analisis}

Hasil Uji Normalitas pada penelitian ini menghasilkan grafik normal P-P Plot yang menunjukkan titik-titik nilai residual menyebar di garis diagonal dan penyebarannya mengikuti arah garis diagonal. Sehingga data pada variabel Komunikasi, Disiplin Kerja dan Kinerja Karyawan terdistribusi normal dan dapat digunakan dalam model regresi karena memenuhi asumsi normalitas.

Dari hasil pengujian multikolinearitas, diperoleh masing-masing variabel independent memiliki nilai Tolerance $=$ 0.678 dan VIF $=1.475$. Karena nilai tolerance lebih besar dari pada persyaratan minimal $(0.678>0.2)$ dan nilai VIF lebih rendah dari persyaratan maksimal $(1.475<$ 10) maka dapat disimpulkan bahwa analisis regresi linier ganda tidak memiliki masalah multikolinieritas (model yang dikembangkan sudah tepat).

Nilai Durbin Watson hasil perhitungan adalah sebesar $\mathrm{DW}=2.149$. Berdasarkan kategori yang telah ada, nilai DW termasuk dalam range $1.65<\mathrm{DW}$ $(2.149)<2.35$ yang berarti tidak terjadi gejala autokorelasi. Oleh karena itu, analisis regresi linier berganda dapat dilanjutkan.

Grafik Scatter Plot memperlihatkan bahwa titik-titik hasil perhitungan menyebar secara acak di atas dan di bawah titik origin serta tidak membentuk pola tertentu. Hal ini dapat dikatakan bahwa hasil analisis regresi ganda benar-benar linier karena tidak memiliki masalah Heteroskedatisitas, sehingga analisis linier ganda dapat dilanjutkan.

Karena persyaratan analisis (asumsi klasik) telah terpenuhi, yaitu memenuhi normalitas, tidak terjadi autokorelasi, tidak terjadi multikolinearitas, tidak terjadi heteroskedastisitas maka analisis regresi linier ganda dapat dilanjutkan. Data yang digunakan adalah data yang telah diuji tanpa melakukan perubahan karena persyaratan asumsi klasik telah terpenuhi semua. 


\section{Uji Model}

Dari Tabel 2 dapat diketahui bahwa nilai koefisien determinasi ( $R$ Square) yang diperoleh sebesar 0.712. Nilai R2 $=0.712$ menunjukkan bahwa X1 (Komunikasi) dan X2 (Disiplin Kerja) dalam model secara bersama-sama mampu menjelaskan $71.2 \%$ variasi Y (Kinerja Karyawan) sedangkan $28.8 \%$ variasi $\mathrm{Y}$ lainnya dijelaskan oleh variabel lain yang tidak diteliti.
Berdasarkan tabel Anova nilai $\mathrm{F}$ hitung = 64.192 dengan probabilitas nilai Sig 0.000. Maka dapat disimpulkan nilai $\mathrm{F}$ hitung (64.192) > F tabel (3.175) dan Sig (0.000) < a (0.05) dengan demikian Ho ditolak dan $\mathrm{Ha}$ diterima yang memiliki arti model hasil penelitian layak digunakan untuk menjelaskan secara simultan pengaruh Komunikasi dan Disiplin Kerja terhadap Kinerja Karyawan pada PT Astra Visteon Indonesia adalah signifikan.

Tabel 2. Hasil Koefisien Determinasi

\begin{tabular}{cccccc}
\hline Model & R & R Square & Adj. R Square & F & Sig. F \\
\hline Disiplin + Komunikasi $\rightarrow$ Kinerja & 0,844 & 0,712 & 0,701 & 64,192 & 0,000 \\
\hline
\end{tabular}

Sumber : Penelitian yang diolah, 2021

Tabel 3. Koefisien Regresi Linier Ganda Komunikasi dan Disiplin Kerja terhadap Kinerja Karyawan

\begin{tabular}{clccc}
\hline Dependen & Independen & $\mathrm{B}$ & $\mathrm{t}$ & Sig. \\
\hline Kinerja & (Konstanta) & 16,890 & 8,256 & 0,000 \\
& Komunikasi & 0,259 & 4,382 & 0,000 \\
& Disiplin Kerja & 0,413 & 6,117 & 0,000 \\
\hline
\end{tabular}

Sumber : Penelitian yang diolah, 2021

\section{Model Persamaan dan Pengujian}

Dari tabel 3 dapat dibentuk model persamaan regresi sebagai berikut : $\mathrm{Y}=16.890+0.259 \mathrm{X} 1+0.413 \mathrm{X} 2 \ldots \ldots \ldots \ldots 2)$

Nilai $\mathrm{t}$ hitung variabel Komunikasi adalah sebesar 4.382 dengan probabilitas Sig $=0.000$. karena nilai $\mathrm{t}$ hitung $(4.382)>\mathrm{t}$ tabel (2.007) dan Sig $(0.000)<(0.05)$, maka Ho ditolak dan Ha diterima. Jadi, dapat disimpulkan bahwa secara parsial pengaruh Komunikasi terhadap Kinerja Karyawan adalah signifikan.

Nilai t hitung variabel Disiplin Kerja adalah sebesar 6.117 dengan probabilitas Sig $=0.000$. karena nilai $\mathrm{t}$ hitung $(6.117)>\mathrm{t}$ tabel (2.007) dan Sig $(0.000)<(0.05)$, maka Ho ditolak dan Ha diterima. Jadi, dapat disimpulkan bahwa secara parsial pengaruh Disiplin Kerja terhadap Kinerja Karyawan adalah signifikan.

\section{PEMBAHASAN}

Pengukuran variabel penelitian dilakukan dengan menggunakan kuesioner yang dikembangkan dari indikator pada masing-masing variabel penelitian. Dari hasil uji validitas terhadap masing-masing variabel penelitian ditemukan bahwa seluruh item pernyataan pada setiap variabel telah valid. Melalui uji reliabilitas ditemukan bahwa seluruh butir pernyataan yang telah valid pada masingmasing variabel penelitian dapat dibuktikan reliabilitasnya. Karena kuesioner telah valid dan reliabel maka kuesioner penelitian merupakan alat yang handal untuk mengukur masing-masing variabel penelitian.Dari hasil uji validitas terhadap masing-masing variabel penelitian ditemukan bahwa seluruh item 
pernyataan pada setiap variabel telah valid. Melalui uji reliabilitas ditemukan bahwa seluruh butir pernyataan yang telah valid pada masing-masing variabel penelitian dapat dibuktikan reliabilitasnya.

Analisis deskriptif terhadap variabel penelitian menghasilkan temuan yang relatif sama untuk semua variabel penelitian dimana persepsi responden terhadap Komunikasi, Disiplin Kerja dan Kinerja Karyawan cenderung baik. Penelitian menghasilkan model yang layak dimana model hasil penelitian mampu menjelaskan $71.2 \%$ variasi Kinerja Karyawan karena masukan faktor Komunikasi dan Disiplin Kerja.

\section{Pengaruh Komunikasi terhadap Kinerja Karyawan}

Berdasarkan hasil penelitian menunjukkan bahwa Komunikasi berpengaruh signifikan berdasarkan $t$ hitung (4.382) $>\mathrm{t}$ tabel (2.007) dan sig $(0.000)<(0.05)$, terhadap kinerja karyawan.

Hasil yang didapat pada penelitian ini sejalan dengan penelitian yang sudah dilakukan oleh Ardianto (2016) bahwa komunikasi berpengaruh positif dan signifikan terhadap kinerja karyawan pada Shinta Catering Godean Yogyakarta. Selain itu, penelitian ini pun sejalan dengan penelitian yang dilakukan oleh Wandi, dkk (2019) yang menghasilkan kesimpulan bahwa bahwa komunikasi berpengaruh positif dan signifikan terhadap kinerja pegawai pada Badan Penanggulangan Bencana Daerah (BPBD) Provinsi Banten.

\section{Pengaruh Disiplin Kerja terhadap Kinerja Karyawan}

Berdasarkan hasil penelitian menunjukkan bahwa Disiplin Kerja berpengaruh signifikan berdasarkan $t$ hitung (6.117) $>\mathrm{t}$ tabel (2.007) dan sig $(0.000)<(0.05)$, terhadap kinerja karyawan. Hasil yang didapat pada penelitian ini sejalan dengan penelitian yang sudah dilakukan oleh Pangarso dan Susanti
(2016) bahwa disiplin kerja memiliki pengaruh yang positif dan signifikan terhadap kinerja. Selain itu, penelitian ini pun sejalan dengan penelitian yang dilakukan oleh Liyas dan Primadi (2017) yang menghasilkan kesimpulan bahwa disiplin kerja memiliki pengaruh yang positif dan signifikan terhadap kinerja karyawan di Bank Perkreditan Rakyat.

\section{KESIMPULAN}

Komunikasi memiliki pengaruh terhadap Kinerja Karyawan pada PT Astra Visteon Indonesia dengan arah positif sebesar b1 $=0.259$, artinya semakin tinggi Komunikasi maka semakin tinggi pula Kinerja Karyawan dan nilai Komunikasi secara parsial berpengaruh signifikan terhadap Kinerja Karyawan. Disiplin Kerja memiliki pengaruh terhadap Kinerja Karyawan pada PT Astra Visteon Indonesia dengan arah positif sebesar b2 = 0.413, artinya semakin tinggi Disiplin Kerja maka semakin tinggi pula Kinerja Karyawan dan nilai Disiplin Kerja secara parsial berpengaruh signifikan terhadap Kinerja Karyawan.

PT Astra Visteon Indonesia disarankan untuk meningkatkan komunikasi antar karyawan sehingga dapat memperlancar kegiatan perusahaan serta terbukti berpengaruh terhadap kinerja karyawan. Selain meningkatkan komunikasi, PT Astra Visteon Indonesia harus dapat mempertahankan dan meningkatkan Disiplin Kerja Karyawan agar karyawan dapat lebih bertanggung jawab atas pekerjaan yang diberikan dan hasil kerja pun akan maksimal, hal tersebut dapat dibuktikan dengan adanya pengaruh disiplin kerja terhadap kinerja karyawan.

Untuk penelitian selanjutnya peneliti menyarankan kepada perusahaan atau peneliti selanjutnya untuk meneliti pengaruh variabel lain yang dinilai mampu untuk meningkatkan kinerja karyawan di PT Astra Visteon Indonesia. 


\section{DAFTAR PUSTAKA}

Ardiansyah, D. O. 2016. Pengaruh Komunikasi Terhadap Kinerja Karyawan Dengan Dimediasi Oleh Kepuasan Kerja (Studi Pada Bagian Produksi Pabrik Kertas PT. Setia Kawan Makmur Sejahtera Tulungagung). Jurnal Bisnis dan Manajemen, 3 (1).

Ardianto, H. 2016. Pengaruh Komunikasi, Motivasi Dan Lingkungan Kerja Terhadap Kinerja Karyawan Shinta Catering Godean Yogyakarta (Doctoral dissertation, Universitas PGRI Yogyakarta).

Bogdan dan Taylor. 1975. Metodologi Penelitian Kualitatif. Bandung: Remadja Karya.

Damayanti, R., Hanafi, A., \& Cahyadi, A. 2018. Pengaruh Kepuasan Kerja Terhadap Kinerja Karyawan (Studi Kasus Karyawan Non Medis Rs Islam Siti Khadijah Palembang). Jurnal Ilmiah Manajemen Bisnis Dan Terapan, 2, 75-86.

Dewi, Sutrisna. 2007. Komunikasi Bisnis. Yogyakarta: Penerbit Andi.

Fathoni, A. 2006. Metodologi penelitian dan teknik penyusunan skripsi. Jakarta : Rineka Cipta.

Ghozali, I., 2005. Analisis Multivariate Lanjutan dengan Program SPSS. Semarang: Badan Penerbit Universitas Diponegoro.

Gulo, W. 2010. Metodologi Penelitian, cetakan keenam. Jakarta: PT Grasindo.

Hasibuan, Malayu. 2007. Manajemen Sumber Daya Manusia. Jakarta : Bumi Aksara.

Hasibuan, M. S. 2009. Manajemen Dasar, Pengertian, dan Masalah, Edisi Revisi. Jakarta : Bumi Aksa.

Ibrahim, M., \& Meilany, P. 2015. Pengaruh Disiplin Kerja Terhadap Kinerja Karyawan (Kasus Bagian Operasional PT. Indah Logistik Cargo Cabang Pekanbaru) (Doctoral dissertation, Riau University).

Kasmawati, K. 2014. Pengaruh Lingkungan Kerja terhadap Kinerja Karyawan pada PT. Sermani Steel Makassar (Doctoral dissertation, Universitas Islam Negeri Alauddin Makassar).

Liyas, J. N., \& Primadi, R. 2017. Pengaruh Disiplin Kerja Terhadap Kinerja Karyawan Pada Bank Perkreditan Rakyat. Al-Masraf: Jurnal Lembaga Keuangan dan Perbankan, 2 (1), 1726.

Mangkunegara, A. P. 2006. Perencanaan dan Pengembangan Manajemen Sumber Daya Manusia. Bandung : PT Refika Aditama.

Mangkunegara, Anwar Prabu, 2001. Manajemen Sumber Daya Manusia Perusahaan. Jakarta : PT. Remaja Rosdakarya.

Mulyana, Deddy. 2001. Ilmu Komunikasi Suatu Pengantar. Bandung: Remaja Rosdakarya.

Mulyanto, H., \& Wulandari, A. 2010). Penelitian: Metode \& Analisis. Semarang: CV. Agung.

Pangarso, A., \& Susanti, P. I. 2016. Pengaruh disiplin kerja terhadap kinerja pegawai di biro pelayanan sosial dasar sekretariat daerah provinsi Jawa Barat. Jurnal Manajemen Teori dan Terapan (Journal of Theory and Applied Management), 9 (2).

Panggabean, P. 2017. Analisis Sistem Pelatihan Kinerja Karyawan pada PT. Bhanda Ghara Reksa (Persero). Jurnal Ilmiah METHONOMI, 3(2), 1-6.

Prawirosentono, S. 2008. Perilaku Organisasi. Yogyakarta: Andi.

Sastrohardiwiryo, B. S. 2005. Management of Indonesian Workers. Administrative and Operational Approaches. Jakarta: Bumi Literacy.

Sugiyono. 2013. Metode Penelitian Administrasi. Bandung: Alfabeta.

Sutrisno, Edi. 2009. Manajemen Sumber Daya Manusia. Jakarta : Prenadamedia Group.

Tegar, Nanang. 2019. Manajemen SDM dan Karyawan. Yogyakarta : Quadrant. 
Wandi, D., Adha, S., \& Asriyah, I. 2019. Pengaruh Komunikasi Terhadap Kinerja Pegawai Pada Badan Penanggulangan Bencana Daerah (Bpbd) Provinsi Banten. Jurnal Ekonomi Vokasi, 2(2), 18-30.

Wahjono, S. I. 2010. Perilaku Organisasi. Yogyakarta: Graha Ilmu.

Yani, M. 2012. Manajemen Sumber Daya Manusia. Jakarta : Mitra Wacana Media 